\title{
Who Has the Right to the Post-Socialist City? Writing Poland as the Other of Marxist Geographical Materialism
}

\section{Kamil Rusiłowicz}

\section{(2) OpenEdition Journals}

Electronic version

URL: https://journals.openedition.org/ejas/11260

DOI: $10.4000 /$ ejas. 11260

ISSN: 1991-9336

Publisher

European Association for American Studies

Electronic reference

Kamil Rusiłowicz, "Who Has the Right to the Post-Socialist City? Writing Poland as the Other of Marxist Geographical Materialism", European journal of American studies [Online], 10-3 | 2015, document 1.3, Online since 31 December 2015, connection on 08 July 2021. URL: http:// journals.openedition.org/ejas/11260 ; DOI: https://doi.org/10.4000/ejas.11260

This text was automatically generated on 8 July 2021 .

Creative Commons License 


\section{Who Has the Right to the Post- Socialist City? Writing Poland as the Other of Marxist Geographical Materialism}

Kamil Rusiłowicz

In 2011, following David Harvey's call for the reconstruction of historical-geographical conditions that became the basis for social formations in late capitalism, Paul Giles proposed a geographical re-reading of the history of American literature that would account for "the multidimensional effects of globalization [that] have configured the premises of U.S. national identity in relation to a wider sphere." ${ }^{\prime 1}$ Looking at the history of American literature geographically, Giles distinguishes two contradictory impulses that shaped the American letters during the post-Civil War period: assimilation and national integration on the one hand, and emphasis on local loyalties on the other. Yet, while seemingly antithetical, the two attitudes complemented each other through a dialogue between centrifugal and centripetal tendencies, ${ }^{2}$ with modernism establishing the local as the synecdoche of national identity at the turn of the nineteenth and twentieth century $^{3}$ and late twenty- and early twenty-first-century writers "struggling to articulate the changed, 
interdependent nature of the relationship between place and planet." 4

Giles's The Global Remapping of American Literature has proved a successful endeavor for at least two reasons. Firstly, it follows a theoretical model based on the changes initiated in a country that, after World War II, became the world's leading economy. ${ }^{5}$ Secondly, a country whose literature recognizes mobility as a national feature is more likely to manufacture subjects willingly undergoing reterritorialization than a country with a history of nostalgia for a national territory. And even though after World War II the immobilization through Fordist-influenced urban planning became the dominant economic model in the United States, American literature was able to enter a dialogue with the lifestyle promoted by the economy based on mass production. By way of comparison, while American writers responded to models of life that coincided with the objectives of the Fordist economy, thus building a tradition of critical representation of reality, the post-World War II Polish literature could not openly engage in a discussion with the official economic order and all polemics with Western models of life were under the scrutiny of the censors. As a result, with the fall of communism in 1989, a new generation of Polish writers found themselves unprepared for an engaged polemical discussion with the postmodern neoliberal world, a discussion that, both in literature and theory, had been taking place in the U.S. since the 1970s.

While Giles's scholarship does not include the study of small American post-industrial towns (also largely overlooked by Harvey), it still manages to provide a complex literary map of the United States: the American South is analyzed in terms of local communities bound by strong kinship ties, with issues of race and economy as a background for social tensions; Philip Roth and John Updike are good examples of writing suburban America; and Don DeLillo and David Foster Wallace write the postmodern, digital United States. Giles chooses both local and globallyaffected literature to remap the history of American letters according to the latitudes delineated by Harvey in The Condition of Postmodernity. At the same time such critically acclaimed novels as Richard Russo's 2001 Empire Falls or Philip Meyer's 2009 American Rust, although overlooked by scholars (including Giles), provide insightful comments upon deindustrialization. Similarly to Harvey's geographical 
materialism, which created its default Other - small factory or rural towns influenced by the shift from Fordism to flexible accumulation - Giles could overlook the problem of unsuccessful deindustrialization due to the bulk of American literature devoted to other pressing issues consuming the world of late capitalism. In other words, Giles's analysis of American literature provides insightful comments on how American writers enter a dialogue with the globalized world theorized by Harvey, yet it overlooks the blind spot of Harvey's criticism. The fact that Giles does not analyze such writers as Russo or Meyer seems a necessary consequence of following the theoretical model that does not list small factory towns among major problems of the globalized world.

If one were to look at the history of Polish literature from Giles's perspective, one of the most general problems concerns geography. Poland's historical and political relation to its territory is a complex dialogue between national identity and shifting geographical conditions. It is the case of a country that for over 100 years produced literature with no material, politically recognized referent. When in 1918 it reappeared on the political map of Europe, its new borders called for a redefinition of the nation's relation to its former territories. Finally, after World War II it underwent another geographical remapping, simultaneously becoming dependent on the political and economic directives from Moscow. As a result of this final change, Polish literature needed to (but officially could not) define itself in relation to the oppressive regime whose imprint is still visible in the architecture of Polish cities. The second major obstacle addressed in the present paper regards the condition of the post-socialist city that resists adaptation to the globalized world of flexible accumulation. Even though Giles did not address the issue of the postsocialist city, small factory American towns excluded from his map of postmodern America bear a striking resemblance to many settings of the Polish literary production written after 1989. Thus the Other of Marxist geographical materialism - small factory towns that failed to successfully accomplish the process of deindustrialization - becomes one of the major literary landscapes of Poland written after the fall of Communism.

When in the 1980s Harvey was describing the transition from the Fordist economy to the economy of flexible accumulation that had been taking place in the 
United States since the 1970s and spreading to other liberal democracies, Poland was still struggling to regain its independence from the communist regime. And when the Iron Curtain finally fell in 1989, the Polish society had to gradually adapt to the conditions of the globalized world. Those who adapted quickly to the rules of free market would profit. Their additional advantage was the ability to navigate within the economic grey zones that the state was yet unable to regulate. Others, brought up in the statecontrolled economy that provided little space for individual initiative, waited for the new political order to fix the economy. Simultaneously, with censorship finally gone, the Polish society got free access to Western cultural models propagated by the most democratic medium of values and attitudes - American movies. Yet before movie theatres became an integral part of Polish shopping malls (that were yet to be built), and before the Polish society got connected to the Internet, the statistical Pole would learn about the American Dream from the vicissitudes of the Dynasty's Carrington family. Thus those who waited for the economic crisis of the 1990s to end often did so in front of their TV sets, identifying with the Hollywood vision of America as a symbol of a better world.

As I argued elsewhere, Harvey's critical theory, while providing a model of the transition from Fordism to flexible accumulation, seems to apply to large American urban centers, overlooking places that were unable to finish the process of deindustrialization. Those post-industrial "ghost towns" become the repressed Other of Harvey's writing. On the one hand, their inhabitants are still trapped within the material space of functionalist architecture designed so that the workers' lives would revolve around the factory. For the benefits offered by what usually was the main employer in the region, they paid with voluntary immobilization: for instance, if the largest employer in the region was a car factory, most of its employees would be given a position that did not require developing such skills as adaptability or geographical mobility. Therefore, while often menial and repetitive, by offering such advantages as full employment, social benefits, housing and welfare, this line of work seemed to successfully tie the workers to their unskilled position and, consequently, to geographical location. In the aftermath of the recession of 1973, many large plants got shut down or relocated and employment in industry got reduced. Those inhabitants of small American industrial towns, suddenly deprived of access to industrial jobs that 
used to be the cornerstone of the economy based on mass production, became the target of worldwide neoliberal (ideological) engineering that promotes mobility and heterogeneity, and rewards its participants with access to the world of wealth advertized in movies, magazines, and on billboards. Unable to adapt to the rules of this new game, yet constantly reminded about the existence of the "right side of the tracks," they became trapped within the material space of Fordism and ideological space of flexible accumulation. ${ }^{6}$

In 1989 the Polish society regained civil and political rights and was granted economic freedom within the neoliberal global market. Simultaneously, it became exposed to Western popular culture promoting neoliberal values. However, the Polish towns and cities continued to function as repositories of the state-controlled past. As stressed by sociologist Karol Kurnicki, it is impossible to distinguish between an "ideological socialist city" and a "post-ideological post-socialist city," for all cities are entangled in ideology, whether Marxist or neoliberal. And since ideology is reproduced in space by subjects, space becomes an arena where ideologies are legitimated or rejected. In other words, for an ideology to be successful it requires social legitimization - the more a society identifies with a given set of ideas, the less visible the ideology. On the other hand, if a society rejects a given set of values, urban space becomes the stage of social discontent. Thus, concludes Kurnicki quoting Žižek, one cannot proclaim the end of ideology, for the post-ideological order is merely more successful at concealing its ideological roots. ${ }^{7}$

During the Polish People's Republic (1945-1989) cities became the space where society expressed its discontent with the worsening conditions of life and lack of political subjectivity, a discontent which ultimately resulted in the overthrowing of the communist regime. In the contemporary Poland, cities such as Gdańsk, Gliwice, Gorzów Wielkopolski, Cracow, Opole, Płock, Poznań, Racibórz, Świdnica, Torun, and Warsaw witness the proliferation of the right to the city movements that - while never completely rejecting the neoliberal order - demand more control over the city. Based on the analysis of a literary representation of the transformation-era Poland, this article investigates the space in-between the socialist and neoliberal city. It is precisely because of the hybrid status that the post-socialist cities in Poland have become a 
testing ground of neoliberal policies. The key questions I am going to address are: What is the position of the postsocialist city within the free-market neoliberal economy? How does the residue of the past built into the fabric of the functionalist space affect its inhabitants? What prevents the residents of the post-socialist city from entering what Harvey calls the space of flexible accumulation? And finally, how can the inhabitants of the post-socialist city reclaim public space?

The novel discussed in this article, Mariusz Sieniewicz's 2003 Czwarte niebo [Fourth Heaven], provides an interesting depiction of the post-socialist city upon the arrival of the neoliberal ideology. The discussion that follows will analyze the spatial organization of the district where the novel takes place, juxtaposing it with social tensions brought about by the arrival of a private-owned cellphone company, leading to an investigation of the position of the post-socialist city within the global space of the free market. This discussion will, in turn, allow for an analysis of the post-socialist city as experienced by its citizens, making it possible to address the central question of this essay: who has the right to the post-socialist city?

\section{II}

Fourth Heaven opens with the description of Zatorze, an old district of the north-eastern city of Olsztyn where the novel takes place. Separated from the rest of the city by railway tracks, "The district came to a standstill in the shadow of the city that has been spreading blindly, swallowing up nearby forests, lakes, and meadows." ${ }^{\circ}$ While the rest of the city grows, Zatorze remains a place without prospects dotted by such establishments as a milk bar for students and homeless people, a once-famous restaurant that has preserved its socialist décor, a closed-down cinema, and a kiosk with the cheapest beer in town. ${ }^{9}$ All of these function as the material reminders of the district's economic collapse. Similarly, the railway tracks become a symbolic borderline that separates Zatorze from the rest of the city. On the one hand, then, Olsztyn from Sieniewicz's novel seems to embrace the post-1989 imperative of economic (and spatial) growth, with regard to both the city's size and the type of cityscape one would encounter if invited to its newer post-1989 districts (although such an invitation is never issued, as the characters rarely cross the tracks). On 
the other hand, the stagnation of Zatorze is a clear marker of growing uneven regional development.

Expanding Ernest Mandel's argument, Edward Soja stresses the fact that "[r]egional underdevelopment is an integral part of extended or expanded reproduction, creating large reservoirs of labour and complementary markets capable of responding to the spasmodic and contradictory flow of capitalist productivity." ${ }_{10}$ From the point of view of profit-oriented economy, Zatorze seems to be a perfect space for neocolonization, both in terms of surplus labor and lack of goods and services. Yet the district proves remarkably self-sufficient. Local businesses are adapted to the needs and resources of the inhabitants, while a high level of unemployment seems a successful counterpoint to the initial attempts at including the district in the globalized world of consumption. Colorful billboards - one of the most recognizable signs of the advent of the new economic order in the post-1989 Polish literature seem in Sieniewicz's words "uncanny, stuffed there by force, by force made happy." ${ }^{11}$ What is more, they are one of few modifications in the local landscape that has remained largely unchanged since the 1950s, when the working-class public housing estates were built adjacent to the prewar tenements. As the narrator puts it, "[t]he district was marked by the immutability gene and all improvements turned out unsatisfactory - often bringing results opposite to the expected ones, usually grotesque." ${ }^{12}$ While it is true that most of the inhabitants of Zatorze have no resources to afford the advertized products, the grotesqueness of the billboards is not a result of the juxtaposition of human subjects with material objects. Rather, public space proves to be an independent actor capable of resistance. While it manages to combine the pre- and the postwar architectural orders, it refuses to absorb yet another layer of meaning, thus refusing to become a postmodern palimpsest. From the very beginning of Fourth Heaven, this refusal is given a spatial dimension of a clash between the communist architecture and the capitalist advertisements. The narrator seems to perceive the residents of the district as an equally immobile part of the landscape as the buildings they inhabit. Displayed "in the windows of the prewar tenements, [the tenants] looked like miniature figures from old postage stamps fading in the stamp album of the greatest philatelist - time," notes the narrator. ${ }^{13}$ Instead of focusing on the inhabitants, the narrator describes the 
urban space as a stage which determines human inertia. The colorful billboards - a sign of commercial desires that drive a large part of the economy of flexible accumulation never become successfully incorporated into the urban landscape of the district, thus failing to reignite individual resourcefulness and become the sign of a successful transition from communism to capitalism. As long as they seem "uncanny," the district remains trapped within the material space of the old regime and the "immutability gene," reflected in the urban space, remains a constant reminder of the inhabitants' exclusion from the post-1989 neoliberal cornucopia.

Giving an account of the debate about the connection between the "centers" of industrial production and the underdeveloped "periphery," Soja points to the neo-Marxist scholars" emphasis on the "core" countries as the source of exploitation and the resultant inequalities in the "peripheral" countries. ${ }^{14}$ This neo-Marxist distrust of the centre is mirrored in Sieniewicz's novel. When a rich investor arrives in Zatorze, planning to open a cellphone factory there, one of the questions raised at the residents' meeting concerns the involvement of foreign capital. ${ }^{15}$ Although the source of the distrust of foreign investors is never explained, it may be interpreted as a remnant of the communist-era official state ideology that indoctrinated Polish citizens into an unquestioned suspicion of capitalism as a source of class struggle and workers' exploitation rooted in the capitalist class control over the means of production. With Marxism-Leninism no longer the official state ideology, the distrust may attest to the perseverance of the spatially-limited version of Marxism. While foreign capital is still perceived as causing workers' alienation, domestic investors are more welcome by Zatorze's population. This shows in the words of an unnamed female character in Fourth Heaven who expresses a utopian desire for independence from the "core," unaware that any brand of capitalism, whether domestic or foreign, "builds upon regional or spatial inequalities as a necessary means for its continued survival." ${ }_{16}$ For even though one can design a map where elements of global market are "so distributed and mixed across firms and sectors that they cancel themselves out . . . leading to no significant areal value . . . this conceivable spatiality of capitalism is an idealized equilibrium that rarely if ever occurs in the persistently disequilibrating world of capitalist development," stresses Soja. ${ }^{17}$ The female character in Fourth Heaven expresses the 
belief in that "idealized equilibrium" criticized by Soja. Interestingly, Sieniewicz's novel modifies Soja's theoretical model by adding to it a geographical limit characteristic for utopian discourses. ${ }^{18}$ While in Soja's reading the limits of the global market are stretched to the point of losing significance, Fourth Heaven provides an illusion of an economy confined within the national borders. What is more, the inhabitants of Zatorze consent to entering the free market only after the utopian status of a self-sufficient national economy is recognized by the investor. Thus the inhabitants and the investor become equally responsible for creating and sustaining an idealized space capable of cancelling out regional or spatial inequalities. However, this economic utopia may be established only after one of the two equally implausible scenarios is implemented: either the "core" of the global market does not affect the Polish economy or Poland develops its own "core" independent of foreign influences and capable of exploiting its national "peripheries." Thus Fourth Heaven depicts an economic paradox: on the one hand, it establishes a market with clearly delineated national borders, seemingly independent of more developed regions of the world; on the other hand, this economy is an unequivocal product of capitalist geographies of inequality described by Soja that Poland became part of after the fall of communism in 1989.

Marxist geographical materialists such as Soja and Harvey, by juxtaposing Marxist critique of capitalism with the analysis of geographical conditions that allow for the formation of economic power relations, prove that space is not an abstract entity that easily yields to rational planning. They oppose the notion of space as commodity that can be used and controlled. Instead, they perceive space as an active element in the process of forming economic relations. For instance, Harvey observes that the transition from Fordism to flexible accumulation was accompanied by a shift from vertical integration to vertical disintegration. ${ }^{19}$ While Fordism attempted to concentrate production in a single area, flexible accumulation disperses it across the globe. Therefore, claims Harvey, the crisis of overaccumulation in 1973 marks the beginning of the process of deindustrialization that not only dismantles the economic relations established by Fordism, but also affects the social tissue of communities shaped by their dependency on the factory. Thanks to the satellite communications systems "[i]t is now possible for a large multinational corporation . . . to operate plants with 
simultaneous decision-making with respect to financial, market, input costs, quality control, and labour process conditions" ${ }^{20}$ in many different locations across the world. As a result, as multinational companies relocate parts of production to regions with cheaper rent and labor, areas shaped by Fordism often get abandoned by multinational capital. Harvey recapitulates this state of affairs by noting that"political economy ... confine[s] our understanding of space and time to its absolute dimensions." ${ }^{21}$ In other words, when considered in abstract, absolute terms, space is perceived as susceptible to colonization, which often results in profit as the main premise for relocating capital. In Harvey's reading, capital treats space as prone to reshaping, often disregarding networks of relations it either encounters upon arrival or leaves behind. However, even though generally true for functionalist architecture and Fordism, the above statement gets amended with the advent of flexible accumulation: "the less important the spatial barriers, the greater the sensitivity of capital to the variations of place within space, and the greater the incentive for places to be differentiated in ways attractive to capital." ${ }^{22}$

Zatorze exemplifies the paradox of flexible accumulation noticed by Harvey. As an underdeveloped part of the free global market it seems attractive to capital; yet, it remains a local geography shaped by spatial, social, and economic relations established during communism. The fact that Zatorze remains an underdeveloped place turns out to be the greatest obstacle in incorporating the district into the free market. Zatorze never becomes the abstract space of the neoliberal economy. Or, to put it another way, numerous borders that confine the space are reinforced rather than erased. The tracks separate Zatorze from the rest of the city in the same way as the national borders separate Poland from its still suspicious-looking political and economic allies. What is more, the cellphone company, by employing only women from the district, strengthens the exclusion of Zatorze from the rest of the city as this employment strategy prevents Olsztyn's other inhabitants from crossing the tracks. This strategy of exclusion seems to fulfill a promise that the flow of capital can be controlled from and sustained within an underdeveloped part of the globalized world. Interestingly, the inhabitants of the district who express their distrust of the new company seem so preoccupied with the origin of the capital that they disregard the fact that the cases for cell phones are made in 
China - a clear example that Zatorze has become part of the global free market. Therefore, as long as the money they are bought with is said to be Polish, the final product may be a result of the global uneven development that invites multinational companies to search for rent- and labor-friendly regions around the world. Even though the geographical transfer of value takes place, all its unwanted consequences, the major one being the arrival of capitalism with its tendency to exploit underdeveloped parts of the globe, seem to get cancelled within the symbolic borders of Zatorze. However, in order to maintain the illusion of selfsustainability, a visible façade of limits must be created, disguising places where spatial barriers get crossed. While the inflowing capital challenges the stability of the border between Zatorze and the rest of the city, its arrival is justified through the strengthening of another, national frame that the Zatorze population can identify with as Polish citizens. But shifting one border implies the instability of all frames, and the intrinsically contradictory process of negotiating limits to capital brings about unexpected consequences. While some inhabitants of Zatorze seek employment in the cellphone company, thus expressing their willingness to become part of the neoliberal economy, others openly express their radical opposition to any form of capital, whether foreign or national. For example, the speech given by two radicals, Owiewka and Lew, incorporates key elements of the post-1989 populist discourse: distrust of capital that must have its origin in exploitation; disappointment with consumerism; opposition to poverty and the collapse of Polish agriculture; fear of being under the influence of foreign superpowers such as China or Russia combined with the opposition to regulations introduced by the European Union; conviction that Poland is constantly being betrayed and sold; opposition to rewriting the Polish historical metanarrative in a way that would recognize such shameful events as the Jedwabne and Kielce pogroms, and March 1968; and finally, an attempt to name the enemy responsible for the above mentioned problems - politicians who squandered the achievements of the Solidarity movement, the Church, Jewish communists, and homosexuals. The speech ends with a comment on George W. Bush's "war on terror" that is presented as a totalitarian attempt to claim territories that still remain outside the influence of the United States. Here Lew sympathizes with violent attempts at destabilizing the global order, 
suggesting that a peaceful solution is part of the neoliberal ideology introduced by the United States with the Pope's blessing, and therefore cannot bring about any change. ${ }^{23}$

However, an unsuccessful attempt at gaining social legitimization through negotiating local borders is not the only spatial reason for the cellphone factory's failure. Equally important seems the way that restructuring is (not) conducted in the district. Commenting upon restructuring in a different context, Soja stresses that in order for the process to be successful, old social structures must first be disassembled (or their power over citizens' lives at least undermined) to be replaced with new ones. During successful restructuring, "[t]he old order is sufficiently strained to preclude conventional patchwork adaptation and to demand significant structural change instead." ${ }^{24}$ The factory in Fourth Heaven is not established on the ruins of the old order but next to it. The investor attempts to profit from the underdevelopment of the district, maneuvering between the well-established social frustrations stemming from impoverishment and growing nationalism. While the cellphone plant is erected in the place of the old cinema, the rest of the district does not undergo any restructuring, remaining the vestige of a culture incompatible with the neoliberal ideology. For Zatorze's population, whose significant part remains unemployed, everyday afternoon walks become rituals acted out within the post-socialist space that solidify social inertia. ${ }^{25}$ Similarly, the spatial proximity of the inhabitants of Zatorze, a result of both the physical layout of the district and the flagship communistera public housing architecture, seems to serve two interlinked purposes: sustaining habit and executing control. Firstly, it anaesthetizes the inhabitants to the unchanging rhythms of the district. Each Sunday afternoon they fill their window seats to observe the courtyards in front of their buildings, thus recreating a social ritual of habit. ${ }^{26}$ For while they may be observing the courtyard curious for something to happen (even though it rarely does), it is equally plausible that the incentive behind the ritual is not boredom but fear of change, and the gaze's function is to freeze space and its inhabitants in a neverchanging state of inertia. Therefore, the second function of socialist architecture that stems from constant visual surveillance is the creation of an environment susceptible to social control. 
In6 a manner similar to Jeremy Bentham's Panopticon, the communist-era apartment block disciplines its inhabitants to exercise control over themselves. As stressed by Michel Foucault, "the major effect of Panopticon [is] to induce in the inmate a state of permanent visibility that assures the automatic functioning of power." ${ }^{27}$ Similarly to the Panopticon, which "sustain[s] a power relation independent of the person who exercises it," ${ }_{28}$ socialist architecture places subjects within an environment capable of establishing power relations even without the regime that originated it. Additionally, even though it is theoretically possible to withdraw from the public space into the confines of one's apartment, paper-thin and soundtransmitting walls make it impossible to erect an impenetrable border between the inside and the outside. Smells of cooked food, coffee, or perfumes escape apartments becoming public testimonies to private lives. ${ }^{29}$ Thus an attempt to escape the gaze of neighbors is merely a manifestation of one's need for privacy that cannot be fulfilled.

However, Zygmunt Bauman stresses the fact that the residents of the Panopticon, in exchange for their submission to constant surveillance, are granted the sense of security derived from the predictability of daily rhythms. ${ }^{30}$ All residents have to accept the rules that organize a given space, for these rules guarantee a community's harmony. That is why when a person deemed unfit by the neighbors moves into an apartment block, the latter take steps that will result in that person's eviction. By way of example, when a woman and her HIV-positive son move into the apartment block of the main protagonist of Fourth Heaven, the majority of tenants sign a petition addressed to the housing association demanding the woman's eviction. Even though the tenants demand peace in exchange for the taxes and the rent they pay, ${ }^{31}$ the fact that the sick son never disturbed that peace (unlike the protagonist, Zygmunt Drzeźniak, who is a constant nuisance to other tenants, yet whose excesses never result in his eviction) points to a motive different than the one given by the tenants. One's belonging to the local community endows one with the right to delineate borders that separate fellow citizens from strangers, making legitimization a process negotiated from within the district. Even though the woman and her HIVpositive son pay the same taxes as other tenants, their status of newcomers places them in an inferior position to 
the Zatorze community. While economic capital may be a prerequisite for entry into a neighborhood, it is the wellestablished community that holds control over space by granting newcomers insider status. That is why Zygmunt Drzeźniak, whose "parents obtained a public housing apartment in the new district" ${ }^{32}$ during the communist era, never gets evicted. Although he is a constant nuisance to other tenants, his old-timer status protects him against eviction. Interestingly, with the collapse of the communist regime and the advent of the free market economy, public housing is no longer available. Money falls short of granting newcomers access to a close-knit community and the privilege to modify the rules of its functioning. Zatorze is an example of a community so indebted to its communist origin that any attempt at reinventing the collective in a post-socialist reality seems to lack social legitimization. As a result, a paradoxical situation occurs: while the communist regime lost social legitimization and was overthrown, the citizens cultivate the communist-granted base of community ties, successfully opposing the advent of neoliberal urban politics. And since it is impossible to turn back time and restore state-controlled housing cooperatives, any inflow of new inhabitants deemed unfit by the community will meet with the residents' resistance. ${ }^{33}$

The above discussion presents a rather pessimistic view of the post-socialist city as a place organized by its internal logic that neither capital nor individuals can bend to their needs. At this point it seems appropriate to pose the final question: who does the post-socialist city described by Sieniewicz really belong to? To answer this question, I would like to propose a change of perspective. While Soja and Harvey provided valuable theoretical tools for analyzing the processes that take place in Zatorze upon the arrival of the neoliberal economy, Michel de Certeau's theory of "spatial practices," developed in his book The Practice of Everyday Life (1984) offers an illuminating perspective on the city as experienced by its citizens.

De Certeau begins his project of "spatial practices" with a description of Manhattan seen from the 1370 foot tower of World Trade Center. According to de Certeau, this scopic vision "continues to construct the fiction that creates readers, makes the complexity of the city readable, and immobilizes its opaque mobility in a transparent text." ${ }^{34}$ To this God-like project of city planners he opposes the city of its ordinary practitioners, who, immersed in the fragmented 
space of New York, are never granted the luxury of a totalizing viewpoint. Instead of becoming voyeurs, they experience the city through walking, their knowledge never limited to one, superior sense. The city as a concept devised by urban planners, claims de Certeau, rests upon the possibility of three operations: the creation of rationally organized space; the repression of the tactics of users; and the creation of the city as a universal and autonomous subject. In theory, the "Concept-city" redistributes its parts, simultaneously creating "waste products" to be readmitted into the city as it develops and becomes capable of reintroducing excess into a profitable economy of exchange. In reality, continues de Certeau, these processes do not account for space as experienced by its users, resulting in a totalizing project based on exclusion. The unprofitable peripheries can be readmitted into the city only after fulfilling scientific, political, or economic criteria, thus yielding to the requirements of the city seen as a transparent text. ${ }^{35}$ However, while "in discourse the city serves as a totalizing and almost mythical landmark for socioeconomic and political strategies, urban life increasingly permits the re-emergence of the element that the urbanistic project excluded." ${ }_{36}$

If oone considers Zatorze from the point of view of de Certeau's analysis, it seems analogous to the "waste products" that the city produces as a consequence of its development. Both its economic status and the location situate the district at the periphery of Olsztyn, excluded, yet in theory susceptible to readmission. However, while de Certeau seems optimistic about the possibility of reclaiming the city through spatial practices of its inhabitants, the "walking rhetorics" of the characters in Fourth Heaven provide an interesting counterpoint to de Certeau's view. According to de Certeau, functionalist totalitarianism seeks to eliminate from the city "local authorities" such as stories and legends that provide the abstract surface of the city with additional layers of meaning that the inhabitants encounter while traversing its districts. "Stories diversify, rumors totalize," claims de Certeau, "stories are becoming private and sink into the secluded places in neighborhoods, families, or individuals, while the rumors propagated by the media cover everything and . . . wipe out or combat any superstitions guilty of still resisting the figure." ${ }^{37}$ The juxtaposition of stories and rumors in The Practice of Everyday Life grants stories a diversifying power, capable 
of resisting the panoptic vision promoted by the city authorities.

Sieniewicz's Fourth Heaven provides an interesting comment on the possibility of maintaining the dichotomy: stories/rumors discussed by de Certeau. Even though information in Fourth Heaven seems to follow along the two channels delineated by de Certeau, neither of them results in a greater diversification of the district. While the local media inform citizens about the opening of the factory, stressing the possibility of new employment for female inhabitants of Zatorze, informal exchange of information between neighbors focuses on the potential threats the factory will bring to the district. While the former use the neoliberal rhetoric of profit, ${ }^{38}$ the latter presents the businessman as Satan, appealing to the Christian background of the inhabitants, simultaneously providing a clear division between good and evil. ${ }^{39}$ By allowing the rumor to spread, the channel of informal exchange proves equally homogenizing as the official media. While the latter operate through formal, disembodied channels, the rumor spreads through informal, embodied encounters acted out in the urban space - a practice de Certeau believes to be more liberating.

After diagnosing the functionalist administration as oppressive, de Certeau proposes a strategy of resistance based on the analysis of practices that managed to resist homogenization and survive in the streets:
one can analyze the microbe-like, singular and plural practices which an urbanistic system was supposed to administer or suppress, but which have outlived its decay; one can follow the swarming activity of these procedures that, far from being regulated or eliminated by panoptic administration, have reinforced themselves in a proliferating illegitimacy, developed and insinuated themselves into the networks of surveillance, and combined in accord with unreadable but stable tactics to the point of constituting everyday regulations and surreptitious creativities that are merely concealed by the frantic mechanisms and discourses of the observational organization. ${ }^{40}$

Zatorze in Sieniewicz's novel seems to simultaneously fit and elude de Certeau's project. Undoubtedly, the space of the post-socialist city is a reservoir of "singular and plural practices" which "have outlived" the decay of the communist regime. Their "illegitimacy," however, is a more problematic issue. The example of the tenants from Zygmunt Drzeźniak's apartment block shows that even though the communist panoptic administration is no longer in power, the inhabitants have created their own network of 
surveillance rooted in the spatial practices established during the former political system. What during the Polish People's Republic was seen as oppressive has become a strategy of resistance to the advent of the neoliberal ideology. Seen from the point of view of Olsztyn's authorities, the inhabitants' resistance to the new economic order must seem unwarranted. As the political and economic system changed, so did the official objectives of urban administration. No longer does it seem profitable to maintain the district's exclusion. Yet while Olsztyn seems ready to readmit Zatorze into the circulation of capital, its inhabitants are disinclined to renounce their independence.

Fourth Heaven depicts a district whose internal spatial organization immunizes it to neoliberal managerial tactics. Michael Hardt and Antonio Negri, describing the working of Empire - what they define as a new political subject that emerged as a consequence of globalization and the decline of sovereignty of nation-states - claim that one mechanism of control it applies is the kind of inclusion that seemingly erases all differences between the members of the globalized world. "Setting aside differences means, in effect, taking away the potential of the various constituent subjectivities. The resulting public space of power neutrality makes possible the establishment and legitimation of a universal notion of right that forms the core of the Empire," claim Hardt and Negri. ${ }^{41}$ The strategy of control through inclusion, made possible by lifting spatial barriers to the flow of capital, products, and people, results in individuals' disempowerment. As they become members of the globalized world, they renounce any possibility to put pressure on multinational capital. What is more, since nation-states become dependent on multinational corporations, it is increasingly more difficult for work-based local communities to negotiate with state authorities. ${ }^{42}$ Fourth Heaven depicts a community unwilling to become part of Hardt and Negri's Empire, refusing to renounce its strong local identity and the power that stems from it. With the railway tracks as a material marker of its socio-spatial and economic exclusion from the remaining part of the city, Zatorze recreates the mechanisms of exclusion within its own borders and forges a collective subjectivity incompatible with a perspective that invalidates the insideoutside dialectics. While de Certeau sees spatial practices as a liberating form of reclaiming the city and Hardt and Negri consider imperial inclusion as yet another form of 
ideological control, Sieniewicz's novel depicts a space that has not yet become part of Empire, nor do spatial practices of its inhabitants result in their liberation.

Interestingly, the opposition to the neoliberal order in Fourth Heaven is not an expression of a higher civic awareness that stands behind numerous initiatives undertaken by right to the city movements. Commenting upon the growing "deficit of the political" in the postmodern world, Hardt and Negri claim that "[t]he urban landscape is shifting from the modern focus on the common square and the public encounter to the closed spaces of malls, freeways, and gated communities." ${ }_{43}$ In a similar manner Harvey proclaims that "[c]apitalist urbanization perpetually tends to destroy the city as a social, political and livable commons." ${ }^{44}$ In order for the city to once again become a political idea capable of shaping civic responsibility, states Krzysztof Nawratek, cities need to strengthen their social capital. Ties between citizens are strong in places where an individual is weak, both in economic and political terms. One of the examples discussed by Nawratek concerns the period of the Polish People's Republic when economic and political deficiencies resulted in strong ties between neighbors. ${ }^{45}$ Finally, working-class communities prove more efficient at controlling place than space, notes Harvey, ${ }^{46}$ which makes them the more likely subjects of successful social revolts. While oversimplified, the above discussion provides an interesting theoretical frame for the analysis of Zatorze, as Sieniewicz's novel seems to comment upon the right to the city in an unexpected manner. Firstly, while it is true that the public spaces of Zatorze have not yet been claimed by capitalist urbanization, they fail to provide a successful background for civic responsibility. While right to the city movements tend to offer pragmatic solutions aimed at reshaping local landscapes in a way that takes into consideration the needs of the citizens, the inhabitants of Zatorze either go to work at the factory or oppose any change in the district, refusing to participate in the creation of a more inhabitant-friendly commons. Therefore, a hypothesis concerning the relation between the postsocialist city and the right to the city movements may be proposed: while, as claimed by Harvey, "capitalist urbanization tends to destroy the city as a social, political and livable commons," it simultaneously creates a space where civic rights may be executed. Sieniewicz's novel illustrates that the post-1989 Polish city has not yet shaped 
citizens capable of social engagement, and civic rights that the collapse of communism granted to the Polish citizens remain a potentiality. Fourth Heaven seems to suggest that the space in-between the socialist and neoliberal city is still marked by the inertia characteristic for the old regime that the citizens would overcome only in moments of high discontent. While right to the city movements adapt the neoliberal imperative of "customized production" to the social production of the city, the radicals in Sieniewicz's novel are incapable of proposing any positive alternative for the district. Instead of engaging in restructuring, they blow up the cellphone factory at the end of the novel. Secondly, strong ties between the inhabitants of Zatorze do not produce social capital capable of reclaiming the district. What during the communist regime was a successful element of social protest, in a neoliberal world can only delay the inevitable advent of foreign capital. Therefore, the communist social capital accumulated within the postsocialist city, instead of becoming part of creative social restructuring, turns into an element of social control, strengthening the district's exclusion. And thirdly, even though the inhabitants of Zatorze prove successful at controlling the district, their power may be the result of Zatorze's peripheral role in Olsztyn's cityscape, a semiautonomy being the result of neglect and lack of interest. Sieniewicz's novel seems to suggest that without a project (either public or private) that ensures a socially-responsible restructuring, and without citizens willing to execute their civic rights, districts such as Zatorze will either continue their economic collapse or become incorporated into the neoliberal order that will destroy their common squares and break social ties between inhabitants. The post-socialist city from Fourth Heaven turns out incapable of providing either.

III

Kim Dovey argues that "[t]he more that the structures and representations of power can be embedded in the framework of everyday life, the less questionable they become and the more effectively they can work. This is what lends built form a prime role as ideology." ${ }_{47}$ Therefore, even though one can give a temporal marker of an economic or political change, and even though space may be a witness to a radical social protest, when the protesting crowds have dispersed with their needs seemingly satisfied, 
space remains largely the same, consolidating old habits, prejudices, and divisions. Mariusz Sieniewicz's Fourth Heaven proves that the fall of communism in 1989 was merely a historical marker unable to bring any social and economic change to places such as Zatorze.

Once again, Edward Soja provides a useful theoretical tool in the analysis of the post-1989 literary representation of the Polish city. Drawing upon Henri Lefebvre's The Production of Space, Soja coins the term Thirdspace which he defines as "a distinct mode of critical spatial awareness that is appropriate to the new scope and significance being brought about in the rebalanced trialectics of spatialityhistoricality-sociality." ${ }_{48}$ By juxtaposing what he believes are the two major modes of spatial thinking - materiality (Firstspace) and discourse (Secondspace) - Soja recognizes a shift in spatial thinking that extends beyond those traditional approaches and synthesizes them into the lived experience of space as the nexus of the material, the historical, and the social. The trialectics of the material, the historical, and the social in Sieniewicz's novel result in a representation of a city whose historical debt to the previous regime is imprinted in the materiality of the district to such an extent that it continues to shape social interactions. As a result, any attempt at the district's patchwork adaptation to the conditions of the neoliberal world that does not account for a significant spatial change meets with social protest.

Since it is impossible to change the dynamics of Thirdspace without reshaping the material, what would a positive spatial restructuring look like? Sieniewicz does not propose a solution, yet his novel seems to offer a rather pessimistic view on the right to the city movements' potential within the space of the post-socialist city. Its citizens may either adapt to the economy of flexible accumulation and leave for cities more successful at completing the transition from Fordism to flexible accumulation, or they can stay and wait for the advent of the neoliberal economy. In no way do I want to suggest that neoliberal spaces are the only ones that need reclaiming. Rather, Fourth Heaven seems to suggest that the postsocialist city in its most extreme form (exemplified by Zatorze) is incapable of forming citizens that could successfully prevent the privatization of their commons if such an event were to take place. 
The present paper did not attempt to present an empirical model of privatization that took place in the post-1989 Poland, since literature creates fictional representations that stress one process at the expense of others. However, Fourth Heaven offers an interesting perspective on the processes that the post-socialist city had undergone after the collapse of communism in 1989. Sieniewicz depicts the city whose materiality, a result of functionalist, communist urban planning, continues to influence social life. He addresses the issue of unexercised civic rights, suggesting that as long as the material imprint of the old regime holds sway over the Polish cities, it is impossible to develop civic attitudes and a sense of entitlement to urban space. Paradoxically, then, until the global capital has claimed Polish cities and privatized public spaces, the only form of protest Polish citizens are capable of involves restaging the social discontent of the Solidarity movement era. Then, the post-socialist city, with its internal divisions strengthened by the spatial organization of districts and communist architecture, consolidates its symbolic borders. Communication is one of the prerequisites of building a responsible civic society. Fourth Heaven seems to suggest that the post-socialist city does belong to its citizens as long as they do not have to interact with the outside world. The moment the neoliberal world crosses the tracks that separate Zatorze from the more capital-friendly parts of Olsztyn, the district's inhabitants prove unsuccessful in either adapting to the new economic order or resisting it. Sieniewicz depicts the post-socialist city as a remnant of the old regime, a vestige of idyllic economic stagnation that no individual effort seems capable of overcoming. Finally, the materiality of the post-socialist city is an important factor in convincing its inhabitants that it is the only city they have the right to.

\section{NOTES}

1. Paul Giles, The Global Remapping of American Literature (Princeton: Princeton University Press, 2011), 1.

2. Ibid., 114-115.

3. Ibid., 11 . 
4. Ibid., 143.

5. In The Condition of Postmodernity, David Harvey describes the shift that took place in the American economy he calls the transition from Fordism to flexible accumulation. According to Harvey, changes initiated by Henry Ford (the introduction of the five-dollar, eight-hour workday, and development of new technologies used in mass production such as the assembly line) shaped the global postwar economy, resulting in a relatively stable economic growth. During the postwar era, employment in industrial production increased as did demand for mass-produced goods. However, the recession of 1973 showed that the postwar economic boom (1945-1973) reached the point where the market could no longer absorb mass-produced goods, resulting in many large plants being shut down or relocated to more rent-friendly regions of the Third World. Often unable to find employment that would require skills developed in their previous jobs, former employees of large factories were forced to show "flexibility with respect to labour processes, labour markets, products, and patterns of consumption" (147), thus adapting to the new economy Harvey christened flexible accumulation. In short, the core-periphery relation of Fordist employment got reversed. While in Fordist economy the core consisted of full time employees with skills easily available in the labor market, in the economy of flexible accumulation it got replaced by employees expected to be geographically mobile and susceptible to reskilling. Similarly, mass production got reduced, gradually replaced with growing employment in service-sector and information-management. See: David Harvey, The Condition of Postmodernity: An Enquiry into the Origins of Cultural Change (Cambridge: Blackwell, 1992).

6. For a detailed discussion, see Kamil Rusiłowicz, "Between Fordism and Flexible Accumulation: Towards the Chronotope of a Post-Industrial 'Ghost Town'," in Americascapes: Americans in/and their Diverse Sceneries, ed. Ewelina Bańka, Mateusz Liwiński, and Kamil Rusiłowicz (Lublin: Wydawnictwo KUL, 2013), 307-318.

7. Karol Kurnicki, "Produkcja miasta postsocjalistycznego," Autoportret 4, no. 36 (2011): 3839.

8. "Dzielnica zastygła w cieniu miasta, które rozrastało się na oślep, pożerając okoliczne lasy, jeziora i łąki.” Mariusz Sieniewicz, Czwarte niebo (Warszawa: Wydawnictwo W.A.B., 2003), 8. [all the quotations from Czwarte niebo in the text are my translations].

9. Ibid., 9-10.

10. Edward Soja, Postmodern Geographies: The Reassertion of Space in Critical Social Theory (London: Verso, 1990), 105.

11. "dziwaczne, wepchnięte na siłę, na siłę uszczęśliwione.” Sieniewicz, Czwarte niebo, 13.

12. “Dzielnicę cechował krnąbrny gen niezmienności i wszelkie ulepszenia dawały niezadowalające efekty - nierzadko przeciwne do oczekiwanych, a najczęściej karykaturalne.” Ibid., 13.

13. "Lokatorzy w oknach przedwojennych kamienic przypominali miniaturowe postacie ze starych znaczków pocztowych, które blakły włożone do klasera najlepszego z filatelistów - czasu." Ibid., 13.

14. Soja, Postmodern, 110.

15. Sieniewicz, Czwarte niebo, 112.

16. Soja, Postmodern, 107.

17. Ibid., 113. 
18. Thomas More's 1516 Utopia is the most famous example of a perfect state where geographical location serves as a crucial factor in establishing the island's self-sustainability. The sea surrounding Utopia points to the fact that an ideal society can be established only within a total confinement. See Elizabeth Grosz, Architecture from the Outside: Essays on Virtual and Real Space (Massachusetts: MIT Press Cambridge, 2001), 133.

19. David Harvey, The Condition of Postmodernity: An Enquiry into the Origins of Cultural Change (Cambridge: Blackwell, 1992), 284.

20. Ibid., 293.

21. David Harvey, Cosmopolitanism and the Geographies of Freedom (New York: Columbia University Press, 2009), 257.

22. Harvey, The Condition of Postmodernity, 296.

23. Sieniewicz, Czwarte niebo, 156-163.

24. Soja, Postmodern, 159.

25. Sieniewicz, Czwarte niebo, 61-62.

26. Ibid., 15-16.

27. Michel Foucault, Discipline and Punish: The Birth of the Prison, trans. Alan Sheridan (New York: Vintage Books, 1995), 201.

28. Ibid., 201.

29. Sieniewicz, Czwarte niebo, 14.

30. Zygmunt Bauman, Wolność, trans. Joanna Tokarska-Bakir (Kraków: Społeczny Instytut Wydawniczy Znak, 1995), 18-19.

31. Sieniewicz, Czwarte niebo, 150.

32. "rodzice dostali mieszkanie na nowym osiedlu." Ibid., 33.

33. Interestingly, the owner of the cellphone factory seems aware of that fact and tries to use this local particularism to his own benefit. Firstly, the fact that the factory employs only local women may be a sign of the investor's understanding that Zatorze remains a close-knit community that does not tolerate outsiders. Secondly, an attempt at recreating the social relations of the district within the factory may be seen as a way of assuring its productivity. In theory, eliminating internal tensions should increase the factory's efficiency.

34. Michel de Certeau, The Practice of Everyday Life, trans. Steven Rendall (Berkeley: University of California Press, 1988), 92.

35. Ibid., 94-95.

36. Ibid., 95.

37. Ibid., 107-108.

38. Sieniewicz, Czwarte niebo, 93.

39. Ibid., 70, 84 .

40. De Certeau, Practice, 96.

41. Michael Hardt and Antonio Negri, Empire (Cambridge: Harvard University Press, 2001), 198.

42. This seems to coincide with David Harvey's theses on the urban revolution. According to Harvey, if workers are to be successful in defending their rights, a transformation must take place from work-based to community-based struggles. In addition, this transformation must be accompanied by a redefinition of the concept of work that would include non-industrial forms of labor. See David Harvey, Rebel Cities: From the Right to the City to the Urban Revolution (London: Verso, 2012), 138-139.

43. Hardt and Negri, Empire, 188.

44. Harvey, Rebel Cities, 80. 
45. Krzysztof Nawratek, Miasto jako idea polityczna (Kraków: Korporacja Ha! art, 2008), 46.

46. Harvey, The Condition of Postmodernity, 236.

47. Kim Dovey, Framing Places: Mediating Power in Built Form (London: Routledge, 2002), 2.

48. Edward Soja, Thirdspace: Journeys to Los Angeles and Other Real-andImagined Places (Blackwell: Cambridge, 1996), 10.

\section{ABSTRACTS}

The article opens with a thesis that the post-socialist city is not part of the neoliberal world theorized by David Harvey. By way of comparison, the text discusses Paul Giles's The Global Remapping of American Literature which is a successful endeavor because the history of American novel is abundant in examples that fit Harvey's model. The fact that small American factory towns that were unable to successfully accomplish deindustrialization are not accounted for in Giles's scholarship does not diminish the strength of the scholar's argument. However, these towns - the blind spot of Harvey's and Giles's criticism - bear striking resemblance to the postsocialist city present in the post-1989 Polish literature. Therefore, the analysis of the postsocialist city may provide insightful comments on both Polish and American literary representations of small factory towns.

Focusing on Mariusz Sieniewicz's Czwarte niebo, the article analyzes how the post-socialist city remains a repository of the state-controlled past and resists adaptation to the globalized world of flexible accumulation. It attempts to answer the following questions: What is the position of the post-socialist city within the free-market neoliberal economy? How does the residue of the past built into the fabric of the functionalist space affect its inhabitants? What prevents the residents of the post-socialist city from entering what Harvey calls the space of flexible accumulation? And finally, how can the inhabitants of the post-socialist city reclaim public space?

\section{INDEX}

Keywords: Czwarte niebo, David Harvey, Edward Soja, flexible accumulation, Fordism, Mariusz Sieniewicz, Michel de Certeau, post-socialist city, right to the city, space

\section{AUTHOR}

\section{KAMIL RUSIŁOWICZ}

Institute of English Studies, The John Paul II Catholic University of Lublin 